\title{
Institutional personas - Dis/harmonic representations of higher music education
}

\author{
Nadia Moberg \& Eva Georgii-Hemming \\ School of Music, Theatre and Art, Örebro University
}

\begin{abstract}
Self-promotion and the role of 'brand image' have increased in importance within higher education. Drawing on multimodal material from websites, this paper deals with how institutions for higher music education discursively construct institutional personas. Higher music education represents a novel case that contributes to existing knowledge of how institutions represent themselves because it sits at a particular, unique juncture between perspectives on universities as places for education and places for training. By investigating representations - and the actors, beliefs and customs these include - our results shed light on institutional ideals concerning knowledge and education. In conclusion, the institutional personas are explained as dis/harmonic as fundamental contradictions with educational implications are revealed.
\end{abstract}

Keywords: higher music education, multimodal discourse analysis, academic institutions, university websites

\section{INTRODUCTION}

The marketisation of higher education has been accompanied by universities taking on a communicative style characterised by corporate language (Fairclough, 1993). While long acknowledged as a general trend, there is a diversity in the degree to which institutions have adapted to marketisation discourse (Lažetić, 2019). However, self-promotion has gained increasing importance for higher education institutions (Drew, 2013; Panda, Pandey, Bennett, \& Tian, 2019). While various documents emanating from universities have been studied (e.g. Askehave, 2007; Hartley \& Morphew, 2008; Ledin \& Machin, 20I5; Teo, 2007; Xiong, 20I2), research has also highlighted the importance of web-mediated marketing and recruitment (Bok, 2003; Boyles, 2007; Saichaie \& Morphew, 20I4). Websites have been described as the main method for constructing institutional identity (Lažetić, 2019) and as a way of helping institutions to create emotional ties between themselves and stakeholders (Stensaker, 2007).

Previous studies on university websites have found that students are represented and addressed as consumers (Nasti, Venuti, \& Zollo, 20I7; Zhang \& O’Halloran, 20I3). Rather than knowledge, it is credentials and social mobility which are for sale (Saichaie \& Morphew, 20I4). Images of people - mainly students - and buildings are common on websites across countries (Callahan, 2005). Students appear as protagonists whose quotes and testimonies are used to endorse institutions (Nasti et al., 20I7). Visually, Swedish universities - compared to universities in other countries - rely heavily on photographs. Education is promoted with a focus on

*Correspondence to: nadia.moberg@oru.se

Artiklar och reflektioner är kollegialt granskade. Övriga bidragstyper granskas av redaktionen. Se https://hogreutbildning.se ISSN 2000-7558

(C)2021 Nadia Moberg \& Eva Georgii-Hemming. This is an Open Access article distributed under the terms of the Creative Commons Attribution-NonCommercial 4.0 International License (https://creativecommons.org/licenses/by-nc/4.0/), allowing third parties to share their work (copy, distribute, transmit) and to adapt it, under the condition that the authors are given credit, that the work is not used for commercial purposes, and that in the event of reuse or distribution, the terms of this license are made clear.

Citation: Moberg, N. \& Georgii-Hemming, E. (2021). "Institutional personas - Dis/harmonic representations of higher music education", Högre utbildning, 11(1), 27-40. https://doi.org/10.23865/hu.v11.2394 
outcome rather than process (Saichaie \& Morphew, 20I4), depicted as a lifestyle and personal experience (Zhang \& O'Halloran, 2013).

However, studies of university websites have treated universities as cohesive entities (Chiper, 2006; Nasti et al., 2017; Saichaie \& Morphew, 20I4; Sanigar, 20I3), with little or no attention paid to specific disciplines or educational programmes. Disciplines' distinct characters have often been overlooked by higher education research and it needs to be recognised that disciplinary differences play an important role in shaping institutional identification, beliefs and practices (Söderlind \& Geschwind, 2020). While there are studies indicating that universities use generic representations on websites (Saichaie \& Morphew, 2014) and that disciplinary knowledge is de-emphasised (O'Connor \& Yates, 20I4), these have not involved analysis of specific educational programmes. Differences between websites have primarily been understood in terms of different national cultures (Callahan, 2005), design approaches (Hite \& Railsback, 20IO) or governance regimes (Lažetić, 2019). Such perspectives on the complex organisation that universities constitute may fail to recognise differences therein (Finlay, 2004). We argue that analysis of specific disciplines or programmes would contribute to the field.

In this paper, we explore institutions for higher music education (HME). These represent idiosyncratic educational cultures encompassing tensions between two social fields - the field of art and the field of education (Nerland, 2004). Furthermore, academisation has meant renegotiation of knowledge within these institutions (Georgii-Hemming et al., 20I6; Moberg, 20I9). Applicants to HME institutions are often already acquainted with the milieu through previous relationships or experiences with teachers (Presland, 2005) and students (Brändström \& Wiklund, 1995) within the institutions. Therefore, HME - in particular music performance programmes - may seem peculiar to outsiders as students often apply to a particular institution due to a wish to study under a specific teacher (Presland, 2005). The reputation of teachers could thus - perhaps more than promotional efforts - be considered as key in terms of recruitment.

HME represents a novel case that contributes to existing knowledge of how institutional personas are constructed because it sits at a particular, unique juncture between perspectives on universities as places for education and places for training. By analysing multimodal material from HME websites, our aim is to illuminate how institutions portray themselves. Drawing from critical discourse studies, we develop an analytical approach focusing on three dimensions: portrayals of who the institutions are, what they believe and what they do. Accordingly, at the centre of our analysis are actors (who is included and how), beliefs (what is believed and taken for granted) and customs (what customs and activities are portrayed). We ask: how do HME institutions construct institutional personas? We seek to explain the constructions in relation to educational reforms, institutional traditions and societal conditions.

\section{CONTEXTUALISING HIGHER MUSIC EDUCATION}

This paper focuses on HME in Sweden, with the term itself including institutions which deal with the music profession in any or all of its forms, including artistic practice, teaching, learning, education, and research. In Europe, some of these are departments or schools within a university and some are stand-alone academies or specialist institutions referred to as conservatories or Musikhochschulen. Sometimes 'conservatoire' is used as an umbrella term for all types of music institutions in the context of higher education, including HME institutions offering performing arts education and music teacher education, and carrying out scholarly research. Sometimes HME is used to 'characterise musical studies undertaken in the context 
of Higher Education that have a primary focus upon students' practical and creative development' (AEC, 2009, I5).

In Sweden, there are six HME institutions with roots in different traditions. While three have previously been conservatories for longer or shorter periods, three started as educational schools. Since 1971, all of these institutions have been part of the higher education sector. As such, they are subject to the same statutes, ordinances and regulations as other higher education bodies. Apart from the Royal College of Music, the Schools/Academies of Music are departments within a social science and humanities or arts faculty at a university. This means that these departments are entitled to award first, second and third-cycle qualifications as well as being expected to conduct research. The Royal College of Music is a public sector entity but is also a stand-alone university college which is entitled to award first- and second-cycle qualifications. All institutions have performing arts education, music teacher education and related educational programmes at first and second cycle, (e.g. music therapy or music production), and conduct research within the areas of music education, musicology and artistic practice.

Compared to many other European countries, the conservatory tradition is, in a way, possibly less dominant in Sweden. On the other hand, all of these institutions assess applicants through specially designed entrance examinations, often consisting of live auditions before juries of teachers, and which are rooted in conservatoire traditions. The teaching is traditionally based on the training of craft skills and most instruction is of a one-to-one nature, even if a transition from master-apprentice to student-centred approaches to teaching is happening (Johansson \& Georgii-Hemming, 2020). The three institutions which started life as conservatoires are the Royal College of Music in Stockholm, Malmö Academy of Music and the Academy of Music and Drama (Gothenburg). All have undergone a change from a previously undivided focus on developing individuals' craftsmanship to being part of a system for higher education where different knowledge ideals and research activities form part of their operations. These are the institutions dealt with in this paper.

\section{INSTITUTIONAL PERSONAS}

The term institution generally refers to an established and composite structure that involves humans, shared beliefs, norms and traditions. Institutions consist of both formal rules and informal boundaries, making ways of being, acting and thinking within institutions ideologically constrained (Fairclough, 20IO). Institutional practices are subject to unity and consensus but may also involve struggle and change (Meyer \& Rowan, 2006). We view institutions as relatively fixed by discourse and potentially transformed through discursive struggles. In referring to institutions, we view these both as organisational entities and as sites where different actors and interests play against each other.

In this study, our interest lies beyond achieving a description of institutions' 'images' or what have been called 'projected identities' (Moingeon \& Soenen, 2002). The term persona captures an intentionally assumed character or social role built around specific attitudes and beliefs (Fowler, 2015) held by, and constitutive of, actors within the institutions. As such, an institution's identity and image are interdependent (Gioia, Schultz, \& Corley, 200o). This is what we wish to indicate by using the term (institutional) personas. Our starting point is thus that the representations bear a relation to the material world and, most importantly, that they are ideologically shaped and have social consequences. It is thus the explanation of the representation in relation to social practices within the institutions that drives this study. 


\section{Nadia Moberg \& Eva Georgii-Hemming}

\section{METHODOLOGY}

In order to explore the institutional personas of HME institutions, we treat their websites as multimodal texts, focusing on texts, pictures ${ }^{\mathrm{I}}$ and films. ${ }^{2}$ Multiple authors often create websites, making them co-constructed and malleable (Pauwels, 20I2). As such, the study does not allow us to establish who the developers were, what drove their choices nor whether they followed university guidelines. However, the websites contain pages which appear professionally designed as well as pages produced by institutional actors. Our particular interest lies in music performance programmes with a classical study orientation, which guided the selection of pages. Material was collected from the institutions' (i) home page and the 'about us' page, (ii) pages describing institutional history, teachers and students, as well as music performance programmes at different levels, (iii) pages with presentations of upcoming concerts during the semester, and (iv) pages containing overall descriptions of research, international cooperation and cooperation with the business, public and voluntary sectors.

Our methodological approach is multimodal in scope. Multimodality refers to how a variety of semiotic resources are arranged and interact to create meaning (Kress \& Van Leeuwen, 2006), often in ways that reinforce ideas and views commonly taken for granted (Machin \& Mayr, 20I2). In addition, we assume that there is a dialectic relationship between structures and discursive acts (Fairclough, 2015). That is, while discursive acts bear the marks of social and institutional structures, every such act contributes to stabilising or changing these. For this reason, we move recursively between in-depth analysis of texts and interpretations of how these are embedded in institutional conditions. We seek to analyse how - and explain why - the personas are constructed in a particular way.

Since meaning is created in different ways through, for example, pictures, language or colours (Machin, 2007), we use diverse analytical devices. A network of textual, visual and aural ${ }^{3}$ elements can be used to create meaning online. While considering aspects such as page layout, fonts and colours, our primary effort lay in the main elements of the websites, that is, the text and images. The analytical procedure for texts, in its narrow sense, involved considering (i) representations of social actors (ii) representations of social events (iii) modality and evaluation (iv) assumptions (v) intertextuality (vi) metaphors and figurative expressions (vii) lexical choices and collocations. ${ }^{4}$ For the analysis of images, we looked specifically at (i) participants, (ii) representations of social actors, (iii) agency and action, (iv) poses, objects, settings, framing, lighting,

30 pages, 96 images, 8 films

All material was retrieved from the websites on April $5^{\text {th }}, 2019$.

3 There are few aural elements, perhaps surprisingly since these are websites for HME institutions. There are eight films in total on the chosen pages (which include musical and verbal elements), unevenly distributed. One institution accounts for 6 of the 8 films. These have been analysed with a focus on visual and vocal elements.

4 (i) Such as the use of pronouns and inclusion/exclusion. (ii) How processes, participants and circumstances are represented. For example, the use of nominalisation (where processes are represented as entities with the common consequence of people being absent), active/passive social actors. (iii) What (and to what degree) the texts commit to as true, necessary and as un/desirable, good or bad. (iv) Assumptions about what is good, about what exists and about what is, can or will be. (v) Texts or types of texts that are quoted, alluded to or related to in some fashion. (vi) Use of metaphorical language. (vii) Lexical choices, patterns and relations. 
focus and colours. ${ }^{5}$ Various devices thus assisted us in the in-depth analysis of different semiotic resources, while our interest in understanding the multimodal representations of actors, beliefs and customs is what guided us throughout.

The analytical process began with a collaborative discussion on the material in its totality. Thereafter, we divided our work: one of us being responsible for in-depth analysis of images, while the other devoted her time to texts. Each of us compiled a comprehensive document with detailed descriptions of our analysis of each webpage. These served as a foundation for further analysis. We met repeatedly to discuss interpretations and sift out patterns. Initially, a relatively large number of themes were developed. These were then grouped together in order to present our findings in a fertile way.

\section{FINDINGS}

We present our findings under four themes which demonstrate discursive patterns and interpretations, typical of the material. In Overarching leitmotifs, we deal with how the institutions position themselves by constructing their traits of character. Under Disciplinary dynamics we address how the institutions' area of knowledge is constructed and how various contents relate to each other within the field. Polyphonic rooms entails a focus on central educational environments. Key relations explores the role of actors and relationships within the institutions. In addition, we deal with how we are interpellated as readers by these multimodalities. Finally, we bring these themes together and seek to explain the representations in a discussion of Dis/harmonic personas.

\section{Overarching leitmotifs}

Positioning an institution as a central actor within a community is one way of establishing institutional importance. This is achieved through metaphorical language and lexical choices. For instance, one institution claims its significance by virtue of being 'at the epicentre of events', another emphasises its role as 'an artistic and educational force in local and global community development', a third claims it constitutes 'a hub in Sweden's musical life'. While these statements differ in the degree to which the institutions are portrayed as active, they all attain similar ends. In the first case, the institution claims to be located in a bustling milieu. In the second case, the use of the word 'force' attributes to the institution a capability of moving and impacting others. In the third case, the metaphorical language of being a hub constructs an image of centrality from which musical life in Sweden radiates and converges.

The institutions also position themselves against other institutions that offer HME in acts of performing difference (see Hall, 1990). Whether the difference emphasised revolves around the quality of research, a capability to meet societal challenges and developments, collaborative opportunities offered or specific educational qualities, similar declarative statements are used ('particularly good', 'the only', 'a unique', 'internationally leading'). Building on an assumption that they need to stand out as particularly successful in some area in order to be attractive resonates with marketing logic, where competition is reinforced as vital, also in the public sector.

(i) Individuals/groups. Who is represented, who is not? (ii) Representation of social actors, such as gaze, angle of interaction, distance. (iii) Agency and action. Who is doing what and what is being done? Who is active/passive? (iv) Poses, objects, settings, framing, distance, lighting, focus, colours and their dimensions; brightness/darkness, saturation, shadows. 


\section{Nadia Moberg \& Eva Georgii-Hemming}

Another leitmotif in the institutions' presentations of themselves is an idea of exceeding or stretching boundaries, creating an appearance of diversity and openness as hallmarks. Statements concerning the aforementioned can be described as evaluative, where the desirability of such values is assumed. As a motif it extends across and involves several issues - from an idea of diversity among people within the institutions right through to the idea of pushing musical boundaries, or to the notion of being an international milieu and thinking innovatively. Educational programmes are described as 'international in character' or as representing 'an international study environment'. Moreover, the institutions describe themselves as a 'versatile meeting place for music', an 'open and creative meeting place' or as 'boundary-crossing'. Such representations operate as abstractions over a series of social events and the institutions do not provide specific examples to illustrate how or in what way diversity and openness manifests itself. The leitmotif here becomes a strategy for value creation which is important for the constitution of institutional personas.

One noticeable difference between the institutions lies in how they address prospective students. Two institutions focus mainly on what they offer through assertions (e.g. 'you get to work with guest conductors and soloists', 'you get the opportunity to develop, not only as an instrumentalist but also as a team player', 'gives you a solid foundation', 'you get a lot of room to develop into a technically skilled and versatile musician'). In contrast, the third institution formulates itself through the use of obligational modality (e.g. 'on completion of the education you should...', 'after completing your studies you should have acquired'). Thus, prospective students are interpellated primarily in two different ways. In the latter, this is achieved by using regulatory language ('should') with intertextual links to Swedish higher education legislation. The other institutions express themselves in a more promotional way.

This difference is manifest, too, in image choices. Sizeable, elaborate, colourful, actionoriented and saturated images are used by the institutions with a promotional language, while the other uses fewer, smaller images with light colours. Overall, this institution uses images where denotation seems to be a primary objective, while the others aim rather at awakening connotations and thereby communicating ideas and values. Common to the institutions, however, is that they address readers as you, creating a synthetic personalisation common in advertising (Fairclough, 20I5). There is a similarity in the use of the pronoun 'we'. Often 'we' is used to create an affective sense of belonging. Here it is used rather in ways that render teachers, students and other actors within the institutions of secondary importance. Thus, the institutions refer to themselves as abstract entities, constructing themselves as distinct actors who may possess, offer, educate and so on (e.g. by use of possessive pronouns: 'our teachers', 'our students' or expressions such as '[name of the institution] have a dream team of teachers'). Whilst being educational providers, the institutions also label themselves as, for instance, 'meeting points', 'hosts' or 'organisers'. Furthermore, a clear majority of the pictures used on the websites depict concerts or stage performances with use of lighting typical for such arrangements. The educational facet is thus pushed into the background. Instead, the general idea portrayed through the pictures is that of the institutions as concert arrangers.

\section{Disciplinary dynamics}

The institutional personas are structured around craft as a characterising disciplinary activity. Research - whether artistic or scientific - is generally presented without descriptions of its interplay with the institutional core. Academic progression, where the first and second cycle are intended to combine preparations for the performing profession and qualify students for the 
third cycle of (artistic) research (AEC, 20I4; Harrison, 20I4), is thus unclear. Education-wise, the knowledge dimensions brought into focus are practicing, performing, interpretation and ensemble playing, whilst ergonomics, entrepreneurship, music analysis, mental training and so on are mentioned. Clearly, such educational content builds on presupposed ideas about what competences professional musicians will need in the future. Images, too, strengthen the impression that prospective students will get to play a lot since many depict such situations; the practitioner or the 'doer' is the prototype. This resonates with an idea of the classical musician as a craftsman, characterised by her embodied knowledge and technically skilled praxis that - with reference to the philosophical concept of techné (for philosophical reflections regarding techné, see Varkøy, 2013) - may or may not include ars-dimensions: artistic and creative skills (for further discussions regarding paradigms on the foundation of music as art, craftsmanship and science, see Georgii-Hemming \& Lilliedahl, 20r4; F. V. Nielsen, 2009). The emphasis on musical and technical skills is also broadly in line with the neoliberal trend toward notions of the selfoptimising individual (Bröckling, 20I6).

The dynamic between different research areas is noteworthy, whereby artistic research is portrayed as a superior discipline. Structurally, descriptions of artistic research appear first on general pages concerning ongoing research and in texts dedicated to music-pedagogical research; for example, there are intertextual links concerning artistic research, but not vice versa. Images on the pages about research primarily depict scenic music situations, further creating a hierarchical impression. One institution offers another illustration of how the impression of a hierarchy between research fields is constructed: while scholarly research is illustrated by a black and white documentary-style snapshot of pupils in a classroom setting, artistic research is illustrated by a technically elaborate, expressive image of a cellist. Just as there has been a propensity to value expertise as a musician over expertise as a teacher (Gaunt, 2013), the representations of these research fields follow the same logic.

Readers are also invited to share students' thoughts about their education. Their voices are those recontextualised most vividly on the websites (see also Nasti et al., 20I7): in film clips, by short quotes or through transcripts of interviews. Visually, we find them next to instruments, in practice rooms, in studios or performing concerts. The symbolic contact that may arise when the depicted actors recognise us as viewers is absent. This is supported both through the angle of interaction and the actors' gaze in images. Instead we are observers with no imaginary relationship to the people in the images. As students describe their education, they highlight good opportunities to practice, a milieu characterised by collaboration between students and ease of access to good premises, equipment and concerts. The institutions describe their bachelor and master programmes in a similar vein. Corresponding aspects are thus emphasised, generally in the form of evaluative statements (e.g. 'lots of space to develop into a technically skilled and versatile musician', 'excellent practice and concert venues', 'good opportunities to collaborate with students').

Furthermore, whilst the institutions stress one-to-one tuition as a central aspect of learning, one-to-one teaching situations are portrayed only twice. Assertions regarding the centrality of one-to-one teaching seem to build on an idea that it is vital to assure prospective students of the undeniable and irreplaceable role that one-to-one teaching has (e.g. 'the main subject [the main instrument] is obviously a central part of your education', 'plenty of instrumental teaching', 'the studies largely consist of individual lessons'). The disciplinary core can also be discerned in statements where the institutions express what students are supposed to develop or become: 


\section{Nadia Moberg \& Eva Georgii-Hemming}

We educate instrumentalists for general music life: orchestras of various kinds, county music ensembles, freelance activities, etc.

The programme's focus lies in developing your own music-making as well as your own musicianship and a lot of time is dedicated to instrumental- and rehearsal studies.

The three-year bachelor's programme gives you a solid foundation for working as a professional musician in the national and international classical music scene.

The educational core is clear. The value of inner-directed educational content is amplified through images where actors are depicted in traditional concert situations, seemingly engaged in interaction with their instruments more than with each other. The education is portrayed as anchored in individual cultivation rather than collective development, in introspective rather than extrospective issues. Simultaneously, knowledge is deeply context-dependent as it is tied to the concert room. The focus here is on equipping the practitioner for a future career: on the individuals' own development of musical skills and ability to operate smoothly as a professional musician within an already existing market. It is, as others have observed about higher education more generally, the advancement of individuals that institutions highlight (Saichaie \& Morphew, 20I4). More outwardly-facing issues, such as the ability to contextualise their role as musicians, to ethically consider or to evaluate different artistic approaches, are not emphasised to anywhere near the same degree, if at all. The idea of art as social critique (Bolaños, 2007) or of exercising music in order to question the status quo - in new or provocative ways - is absent.

\section{Key relations}

At this point we wish to distinguish between two different relational aspects: the one created between actors operating within the institutions on the websites (text-internal) and the relationship created between the text and its readers (interpellation). Regarding text-internal relations, the most salient is the one created between the institutions as entities and actors operating therein. As previously observed, the institutions construct themselves as active and relational naming ('our teachers', 'our students') reinforces the impression of the institution - its buildings and its rooms - as an actor with whom it is possible to have a relationship. Images contribute to this impression. Scenic images are symbolic rather than documentary. As concert rooms embrace actors, they connote an idea of the 'professional musician at work'. Whichever scene is depicted, images of concert rooms - due to them being representations of musicians within their habitat - become significant. Therefore, the institutions become personalised and a close relationship between them and their actors is simulated. Simultaneously, relations between different actors within the institutions are relegated to the background. Links between human actors are thus, at best, obscured.

These websites are filled with nominalisations, meaning that events are represented in abstract ways, processes construed as entities and actors regularly excluded. Albeit not surprising in these kinds of texts, formulations in the passive voice, such as 'teaching is conducted', 'repertoires are planned', 'education takes place' renders relationships between students and teachers as largely absent. In terms of images, students working together in different ensembles are portrayed, while teachers seemingly have no obvious place (see also Callahan, 2005). On a connotative level, the value of meeting and cooperation between students is emphasised. These relationships are also present in evaluative statements where the aforementioned value is assumed ('good opportunities to collaborate with students', 'you and the other students will follow each other', 
'a dynamic study environment with many other skilled students'). Visually, the relations and collaborations we witness are best illustrated in images of ensembles and orchestras. Students in the images either look at their instruments, music stands or, on occasion, at each other. An audience does not seem to be the main recipient of interaction.

With regard to relationships between students and teachers, this is represented most evidently through students' voices, which are recontextualised on the websites and portray teachers as sources of inspiration, enthusiasts and accomplished musicians. Overall, teachers are represented as being at the students' disposal to serve as role models rather than as people holding official positions with the task of providing teaching. Thus, we argue that students depict the institutions as communities of practice rather than as official institutions for higher education. The relationships can therefore be characterised as centred around apprenticeships within a learning environment sans formal teaching (K. Nielsen, 2006). An absence of images depicting teaching situations, as well as a focus on the community between students, further supports this interpretation.

Nominalisations are also used in relation to research. Actors are represented as either passive or omitted entirely (e.g. 'ongoing research projects ... explore', 'both scientific and artistic methods are used', 'the research is inspired by'). In many instances, it is thus the research itself that is constructed as active, as having a will of its own ('the research at [name of the institution] wants to bring forth investigations', 'the research examines questions about music and sound creation', 'the research is inspired by'). Furthermore, images that appear on pages describing research denote the practice that researchers explore, rather than illustrating researchers in the act of exploring. This contributes to an obfuscation of researchers and their activities, and suppresses the complexity of doing research (see also Ledin \& Machin, 2016).

Essentially, as readers we are not invited into imaginary relationships with the actors in the images, and nominalisations contribute strongly to creating a distant relationship by deleting actors and reifying processes of learning, teaching and research. In contrast, the exclusive institutional we conveys a kind of relational attitude aimed at capturing the reader's attention (see Fairclough, 2015).

\section{Polyphonic rooms}

We now turn to central educational environments. Research, concerts, one-to-one teaching and other educational rooms are portrayed as detached from one another. Texts relating to these different rooms are found on separate pages, with minimal intertextual links between them. Descriptions of research and postgraduate education constitute one obvious example, as these texts are isolated on specific pages.

While the institutions claim that one-to-one teaching lays the foundation of the education provided, this is not reflected in the choice of images. In general, pictures of concert situations and stage performances illustrate their activities. Other aspects, such as one-to-one teaching situations or seminars, occur exceptionally rarely. Consequently, we gain no insight into one-to-one lessons as readers. What happens therein seems to be a question between the teacher and the student, reinforcing a view of this signature pedagogy (see Shulman, 2005) as constituting a 'secret garden' (Burwell, Carey, \& Bennett, 20I9; Young, Burwell, \& Pickup, 2003) or as something happening in a 'culture of concealment' (Carey, Bridgstock, Taylor, McWilliam, \& Grant, 2013, p. 359).

Visually, readers are mainly invited to concert rooms and stages. Thus, we are interpellated first and foremost as potential members of an audience, rather than as prospective students or staff. This differs from what others have found to be common on university websites, namely 


\section{Nadia Moberg \& Eva Georgii-Hemming}

images of student life depicting entertaining, athletic or relaxing activities (Nasti et al., 20I7; Saichaie \& Morphew, 20I4). The way readers are interpellated here can be considered as a transparency of what members of the public are invited to, portraying an openness to the buildings and concert arrangements. That openness is echoed in the ease of access to concert calendars. However, while the institutions highlight themselves as organisers of many concerts ('The [name of the institution] organises about 200 concerts each year', 'students and teachers give nearly two hundred concerts and performances per year', 'one of the country's biggest concert organisers'), the basic prerequisite for these, that is, the education, is not emphasised. The question is whether such statements strengthen the factual thesis to any extent. In the end, despite framing the debate in terms of quantity, the number of concerts does not necessarily equate to the quality of the concerts.

\section{A discussion of Dis/harmonic personas}

At this point we would like to round off by illuminating four significant contradictions. Firstly, we have argued that the institutions wish to present themselves in a way that signals boundarytransgression, openness and diversity. On the other hand, images primarily portray young, healthy people, embodying white, Swedish ethnicities. Thus, there is a sparse representation in terms of social diversity (see also Holmqvist, 20I8; Saichaie \& Morphew, 20I4). Moreover, we have ascertained that the concert calendars for one semester reveal that male composers are referred to a little over two hundred times while female composers are mentioned ten times, with almost every composer mentioned having been born in Europe. Students attending HME often have highly educated parents. ${ }^{6}$ At one of the studied institutions, this applies to 63.I per cent of the entrants (UKÄ, n.d.). This disparity is only surpassed by one other institution within higher education in Sweden: the privately-owned Stockholm School of Economics, with 67.4 per cent of parents from higher-education backgrounds (UKÄ, n.d.). According to Statistics Sweden (UKÄ \& SCB, 20I6), Swedish artistic programmes are the subject-area with the fewest students with a foreign background ${ }^{7}$ (I5.5 per cent) (ibid.). Several components therefore contribute to a contradictory image of HME. In many regards, the institutions are deeply rooted in musical (and performing) traditions and constitute socially homogeneous environments. A portrayal of the institutions as melting pots collides with how these institutions have operated traditionally. Rather, musical uniformity and homogeneity in terms of actors have characterised the institutions. Partly, the representations can be explained by branding efforts. However, we argue that the websites also provide a channel to demonstrate meeting national goals regarding, for example, broadening recruitment and participation, internationalisation and gender mainstreaming.

Secondly, these representations convey an introspective focus. According to the national curriculum, students must demonstrate insight into social and ethical issues relating to music's role in society after completed studies (SFS, I993:I00) and institutions are to ensure that research is beneficial for society (SFS, 1992:I434). However, education as well as research is chiefly portrayed

6 In the statistics, highly educated parents mean that at least one parent has a post-secondary education of at least three years. The percentage refers to entrants at the institution in the academic year $2018 / 2019$.

7 In the statistics, foreign background includes foreign-born and Swedish-born students with two foreign-born parents. The percentage refers to entrants at the institution in the academic year $2018 / 2019$. 
as concerning self-exploration of artistic performance and expression from the perspective of artistic actors and activities inside the institutions. The representations show that the function of research activities is to justify and position HME towards other academic fields and towards the professional field of the arts, rather than turning outwards. One plausible explanation for this contradiction lies in the beliefs and customs held by actors within a conservatoire tradition as distinct from university traditions. We argue that the idea of sharing knowledge - commonly referred to as universities' 'third mission' - might mean radically different things within various disciplines. For actors within HME, it could be argued that sharing knowledge contains an idea of sharing musical expertise by giving audiences highly qualitative musical experiences.

Thirdly, we claim that the institutions largely present themselves as concert arrangers, while education is relegated to the background. Students entering music performance programmes are carefully selected, with admission tests claiming to guarantee that the most 'talented' students are chosen (Kingsbury, 1988). This enables institutions to regard students as semi-professionals from day one. Students are thus 'used' as promotion (see also Nasti et al., 2017) but disappear as individual actors within institutional representations. The institutions are bound by state legislation, belong to the public sector and are financed by public funds, which indicates a contradiction between the institutions' primary task of providing education and the representations of themselves as concert arrangers. This can be explained by the strong relationship between education and the professional field, firmly rooted in the institutions' history and knowledge tradition. However, it can also be understood as part of a general trend where universities portray themselves as offering a lifestyle (Zhang \& O'Halloran, 20I3). If so, these representations constitute a romanticised picture of musicians - a lifestyle characterised by stage performances rather than practice in solitude and rehearsals. However, the occupation is often stressful and competitive, involving hierarchical relations and limited space for individual choices (Johansson, 20I2).

The fourth contradiction we wish to highlight is found in representations of one-to-one teaching. While portrayed as a central educational feature, the teaching is virtually invisible, both visually and textually. In the past, scholars have concluded that one-to-one teaching might be considered 'remarkably productive' (Presland, 2005, p. 237) and that teachers view it as 'indispensable' (Gaunt, 2008, p. 230). However, one-to-one teaching has been under debate in Sweden and elsewhere. During the \#MeToo Movement, the 'culture of concealment' (Carey et al., 2013, p. 359) came into question as students testified to how teachers had subjected them to sexual harassment and abuse (Josefson, 2017). The contradiction lies in the fact that while one-to-one teaching is established as indispensable, the teaching is hardly represented. The 'secret garden' (Burwell et al., 2019; Young et al., 2003) is not just secret, but concealed. We interpret this as a manifestation of an exclusive expert culture, where one-to-one teaching is taken for granted.

\section{CONCLUDING REMARKS}

We utilised a critical discourse study approach where focus was placed on how actors, beliefs and customs were constructed on HME institutions' websites. This approach proved to be fruitful in increasing the understanding of institutional personas and in analysing how they discursively represent themselves. Similarities between the analysed institutions are striking and the results show that there is a disciplinary community shared by the HME institutions. Furthermore, our findings indicate an interdiscursive dynamic that - even though the texts are primarily promotional or descriptive in style and emanate from the institutions - reveal both discursive conflict and harmony. 


\section{AUTHOR PRESENTATIONS}

Nadia Moberg is a doctoral student in musicology at the School of Music, Theatre and Art at Örebro University. Her current research interests lie in the field of discourse studies and higher music education. She is a former board member of the Swedish National Union of Students and the Swedish Council for Higher Education and has a broad interest in educational issues.

Eva Georgii-Hemming (PhD) is Professor in Musicology and Head of the School of Music, Theatre and Art, Örebro University, Sweden. Her research focus is on music education, with a particular interest in higher education. She is the principal investigator of the research project Discourses of Academization and the Music Profession in Higher Music Education (DAPHME), funded by Riksbankens Jubileumsfond (2016-2020).

\section{REFERENCES}

AEC (Association Européenne de Conservatoires, Academies de Musique et Musikhochschulen). (2014). Perspectives on 2nd cycle programmes in higher music education. Brussels: Lifelong Learning Programme.

AEC (Association Européenne de Conservatoires, Academies de Musique et Musikhochschulen). (2009). Tuning educational structures in Europe. Reference points for the design and delivery of degree programmes in MUSIC. Bilbao: Publicaciones de la Universidad de Deusto.

Askehave, I. (2007). The impact of marketization on higher education genres - The international student prospectus as a case in point. Discourse Studies, 9(6), 723-742.

Bok, D. (2003). Universities in the marketplace: The commercialization of higher education. Princeton: Princeton University Press.

Bolaños, P. A. (2007). The critical role of art: Adorno between Utopia and Dystopia. Kritike: An Online Journal of Philosophy, 1(1), 25-31.

Boyles, D. R. (2007). Marketing sameness: Consumerism, commercialism, and the status quo. In J. C. Smart (Ed.), Higher education: Handbook of theory and research (pp. 537-582). Dordrecht: Springer Netherlands.

Brändström, S., \& Wiklund, C. (1995). Två musikpedagogiska fält: En studie om kommunal musikskola och musiklärarutbildning. (PhD). Umeå University, Umeå.

Bröckling, U. (2016). The entrepreneurial self: Fabricating a new type of subject. Thousand Oaks, CA: SAGE Publications Ltd.

Burwell, K., Carey, G., \& Bennett, D. (2019). Isolation in studio music teaching: The secret garden. Arts and Humanities in Higher Education, 18(4), 372-394.

Callahan, E. (2005). Cultural similarities and differences in the design of university web sites. Journal of Computer-Mediated Communication, 11(1), 239-273.

Carey, G. M., Bridgstock, R., Taylor, P., McWilliam, E., \& Grant, C. (2013). Characterising one-to-one conservatoire teaching: Some implications of a quantitative analysis. Music Education Research, 15(3), $357-368$.

Chiper, S. (2006). The discourse of Romanian universities. Journal of Organizational Change Management, 19(6), 713-724.

Drew, C. (2013). Elitism for sale: Promoting the elite school online in the competitive educational marketplace. The Australian Journal of Education, 57(2), 174-184.

Fairclough, N. (1993). Critical discourse analysis and the marketization of public discourse. Discourse \& Society, 4(2), 133-168.

Fairclough, N. (2010). Critical discourse analysis: The critical study of language (2 ed.). Harlow: Longman.

Fairclough, N. (2015). Language and power (3 ed.). London: Routledge.

Finlay, I. (2004). Living in an 'entrepreneurial' university. Research in Post-Compulsory Education, 9(3), 417-434.

Fowler, H. W. (2015). Fowler's dictionary of modern English usage. (Fourth edition). Oxford: Oxford University Press. 
Gaunt, H. (2008). One-to-one tuition in a conservatoire: The perceptions of instrumental and vocal teachers. Psychology of Music, 36(2), 215-245.

Gaunt, H. (2013). Promoting professional and paradigm reflection amongst conservatoire teachers in an international community. In H. Westerlund \& H. Gaunt (Eds.), Collaborative learning in higher music education (pp. 49-61). Farnham: Ashgate.

Georgii-Hemming, E., Angelo, E., Gies, S., Johansson, K., Rolle, C., \& Varkøy, Ø. (2016). Artist or researcher? Tradition or innovation? Challenges for performing musician and arts education in Europe. Nordic Research in Music Education, 17(5), 279-292.

Georgii-Hemming, E., \& Lilliedahl, J. (2014). Why "what" matters: On the content dimension of music didactics. Philosophy of Music Education Review, 22(2), 132-155.

Gioia, D., Schultz, M., \& Corley, K. (2000). Organizational identity, image, and adaptive instability. The Academy of Management Review, 25(1), 63-81.

Hall, S. (1990). Cultural identity and diaspora. In J. Rutherford (Ed.), Identity: Community, culture, difference (pp. 222-237). London: Lawrence \& Wishart.

Harrison, S. D. (2014). Research and research education in music performance and pedagogy (2014 ed. Vol. 11). Dordrecht: Springer Netherlands.

Hartley, M., \& Morphew, C. C. (2008). What's being sold and to what end?: A content analysis of college viewbooks. The Journal of Higher Education, 79(6), 671-691.

Hite, N. G., \& Railsback, B. (2010). Analysis of the content and characteristics of university websites with implications for web designers and educators. The Journal of Computer Information Systems, 51(1), $107-113$

Holmqvist, M. (2018). Handels: Maktelitens skola. Stockholm: Atlantis.

Johansson, K. (2012). Experts, entrepreneurs and competence nomads: The skills paradox in higher music education. Music Education Research, 14(1), 45-62.

Johansson, K., \& Georgii-Hemming, E. (2020). Processes of academisation in higher music education: The case of Sweden. British Journal of Music Education, 1-14.

Josefson, C. (2017). Don Juan på musikhögskolan. Radio Sweden, P2 documentary. https://sverigesradio.se/ sida/avsnitt/990113? programid $=4112$

Kingsbury, H. (1988). Music talent and performance: Conservatory cultural system. Philadelphia: Temple University Press.

Kress, G. R., \& Van Leeuwen, T. (2006). Reading images: The grammar of visual design (2 ed.). London: Routledge.

Lažetić, P. (2019). Students and university websites-Consumers of corporate brands or novices in the academic community? Higher Education, 77(6), 995-1013.

Ledin, P., \& Machin, D. (2015). How lists, bullet points and tables recontextualize social practice: A multimodal study of management language in Swedish universities. Critical Discourse Studies, 12(4), 463-481.

Ledin, P., \& Machin, D. (2016). A discourse-design approach to multimodality: The visual communication of neoliberal management discourse. Social Semiotics, 26(1), 1-18.

Machin, D. (2007). Introduction to multimodal analysis. London: Oxford University Press.

Machin, D., \& Mayr, A. (2012). How to do critical discourse analysis: A multimodal introduction. London: Sage.

Meyer, H.-D., \& Rowan, B. (2006). Institutional analysis and the study of education. In H.-D. Meyer \& B. Rowan (Eds.), The new institutionalism in education (pp. 1-13). Albany: State University of New York Press.

Moberg, N. (2019). Academic musicians: How music performance students in Sweden re-/negotiate notions of knowledge and competence. Nordisk Musikkpedagogisk Forskning: Arbok, 19, 53-74.

Moingeon, B., \& Soenen, G. B. (2002). Corporate and organizational identities: Integrating strategy, marketing, communication and organizational perspectives. London: Routledge.

Nasti, C., Venuti, M., \& Zollo, S. A. (2017). UK university websites: A multimodal, corpus-based analysis. International Journal of Language Studies, 11(4), 131-152. 


\section{Nadia Moberg \& Eva Georgii-Hemming}

Nerland, M. (2004). Instrumentalundervisning som kulturell praksis: En diskursorientert studie av hovedinstrumentundervisning i høyere musikkutdanning. (PhD). Norges Musikkhøgskole, Oslo.

Nielsen, F. V. (2009). What is the significance of research for music education in practice? On relations between the practice of and the scientific approach to music education. Philosophy of Music Education Review, 17(1), 22-40.

Nielsen, K. (2006). Apprenticeship at the Academy of Music. International Journal of Education \& the Arts, $7(4), 1-16$.

O'Connor, K., \& Yates, L. (2014). Disciplinary representation on institutional websites: Changing knowledge, changing power? Journal of Educational Administration \& History, 46(1), 1-16.

Panda, S., Pandey, S., Bennett, A., \& Tian, X. (2019). University brand image as competitive advantage: A two-country study. International Journal of Educational Management, 33(2), 234-251.

Pauwels, L. (2012). A multimodal framework for analyzing websites as cultural expressions. Journal of Computer-Mediated Communication, 17(3), 247-265.

Presland, C. (2005). Conservatoire student and instrumental professor: The student perspective on a complex relationship. British Journal of Music Education, 22(3), 237-248.

Saichaie, K., \& Morphew, C. C. (2014). What college and university websites reveal about the purposes of higher education. The Journal of Higher Education, 85(4), 499-530.

Sanigar, M. A. (2013). Selling an education. Universities as commercial entities: A corpus-based study of university websites as self-promotion. Leeds Working Papers in Linguistics and Phonetics, 18, 85-114.

SFS 1993:100. Högskoleförordningen. [The Swedish Higher Education Ordinance]. Stockholm: Riksdagen.

SFS 1992:1434. Högskolelagen. [The Swedish Higher Education Act]. Stockholm: Riksdagen.

Shulman, L. S. (2005). Signature pedagogies in the professions. Daedalus, 134(3), 52-59.

Stensaker, B. (2007). The relationship between branding and organisational change. Higher Education Management and Policy, 19, 13-29.

Söderlind, J., \& Geschwind, L. (2020). Disciplinary differences in academics' perceptions of performance measurement at nordic universities. Higher Education Governance \& Policy, 1(1), 18-31.

Teo, P. (2007). The marketisation of higher education: A comparative case-study of two universities in Singapore. Critical Approaches to Discourse Analysis Across Disciplines, 1(1), 95-111.

UKÄ \& SCB. (2016). Svensk och utländsk bakgrund for studenter 2014/15. Rapport UF 19 SM 1601.

UKÄ. Universitetskanslersämbetet. (n.d.). Högskolan i siffror. [Dataset]. Available at: https://www.uka.se/ statistik--analys/statistikdatabas-hogskolan-i-siffror.html

Varkøy, Ø. (2013). Technical rationality, techne and music education. In P. Burnard, E. Georgii-Hemming, \& S.-E. Holgersen (Eds.), Professional knowledge in music teacher education (pp. 39-50). Farnham: Ashgate.

Xiong, T. (2012). Discourse and marketization of higher education in China: The genre of advertisements for academic posts. Discourse \& Society, 23(3), 318-337.

Young, V., Burwell, K., \& Pickup, D. (2003). Areas of study and teaching strategies instrumental teaching: A case study research project. Music Education Research, 5(2), 139-155.

Zhang, Y., \& O'Halloran, K. (2013). 'Toward a global knowledge enterprise': University websites as portals to the ongoing marketization of higher education. Critical Discourse Studies, 10, 1-18. 